\title{
A new species of Gymnogeophagus from the río Negro and río Tacuarí basins, Uruguay (Teleostei: Perciformes)
}

\author{
Iván González-Bergonzoni ${ }^{1}$, Marcelo Loureiro ${ }^{1}$ and Sebastián Oviedo²
}

The new cichlid species Gymnogeophagus tiraparae is described from the río Negro and río Tacuarí basins (Uruguay). The new species is distinguished from other Gymnogeophagus species by the unique presence of the following characters: adipose hump on head deeper than the dorsal-fin upper border, adipose hump with anterior profile vertical, extending from the upper lip to the dorsal-fin origin, absence of transversal bands on body; two horizontal series of moderately elongated light blue dots between dorsal fin spines, and a series of light blue stripes between soft rays, sometimes merged with the second series of elongated dots, always with a red ground color between series of dots, and caudal fin with dots vertically aligned on its distal border. According to these characters and a recent molecular phylogenetic analysis, the new species is closely related to G. gymnogenys.

A nova espécie de ciclídeo Gymnogeophagus tiraparae é descrita das bacias dos rios Negro e Tacuarí (Uruguai). A nova espécie se distingue das outras pela presença dos seguintes caracteres: gibosidade adiposa na cabeça mais alta que a borda distal da nadadeira dorsal, gibosidade adiposa com perfil anterior vertical, se extendendo desde o lábio superior até a origem da nadadeira dorsal, duas séries de pintas azul celeste levemente ovaladas na parte proximal da nadadeira dorsal e uma série de linhas azul celeste nas porções posterior e distal da nadadeira, algumas vezes fusionadas com uma segunda série de pintas ovaladas e sempre apresentando um fundo vermelho entre as pintas, nadadeira caudal com pintas alinhadas verticalmente na borda distal. De acordo com esses caracteres e uma recente análise filogenética molecular, a nova espécie é proximamente relacionada à G. gymnogenys.

Key words: Cichlidae, Systematics, Neotropical.

\section{Introduction}

The Neotropical cichlid genus Gymnogeophagus Ribeiro can be distinguished from other cichlids by the presence of a forward directed spine on top of the first pterygophore and by the absence of bony supraneurals (Winberberg et al., 1998). Its monophyly has been corroborated by morphological (Reis \& Malabarba, 1988) and molecular (Winberberg et al., 1998; López-Fernández et al., 2005a, b; Pereyra \& García, 2008) analyses. However, as occurs in other Neotropical Cichlidae (Kullander, 2003), species level taxonomy, distribution patterns and reproductive behavioral evolution are still unclear (Winberberg et al., 1998). Part of this confusion possibly arises from the existence of many undescribed species present in the distribution range of the genus.

Endemic to the río de La Plata basin, laguna dos Patos system and rio Tramandaí drainage (Reis \& Malabarba, 1988),
Gymnogeophagus was hypothesized to be composed of two monophyletic lineages (Winberberg et al., 1998). One of them is composed of substrate spawning species: G. rhabdotus Hensel, G. meridionalis Reis \& Malabarba, G. che Casciotta, Gómez \& Toresanni, and two undescribed species (unpublished data). The other lineage is composed of the basal substrate spawning G. setequedas Reis, Malabarba \& Pavanelli, and the mouth brooding G. balzanii Perugia, G. lacustris Reis \& Malabarba, G. labiatus Hensel, G. gymnogenys Hensel, G. australis Eigenmann, G. caaguazuensis Staeck, and at least five undescribed taxa (Winberberg et al., 1998). Pereyra \& García (2008), using citochrome b sequences from specimens of mouth brooding species (G. labiatus, G. gymnogenys, and two undescribed taxa) distributed in the lower río Uruguay and laguna Mirim tributaries, found three well supported monophyletic lineages from which G. gymnogenys would be the sister species. In this article we describe a new species of

${ }^{1}$ Sección Vertebrados, Facultad de Ciencias, Iguá 4225, Montevideo 11400, Uruguay. (IGB) ivan2002uy@hotmail.com.ar; (ML) mapy@fcien.edu.uy

${ }^{2}$ Sección Genética Evolutiva, Facultad de Ciencias, Iguá 4225, Montevideo 11400, Uruguay. soviedo@montevideo.com.uy 
Gymnogeophagus from the río Negro and río Tacuarí basins (Uruguay), that belongs to the dimorphic mouth breeders group, and that corresponds to one of the monophyletic clades found by Pereyra \& García (2008).

\section{Materials and Methods}

Examined material of the new species and comparative material from other Gymnogeophagus species came from the fish collection of the Facultad de Ciencias de la Universidad de la República, Montevideo (ZVC-P), and Museo Nacional de Historia Natural y Antropología (MNHN), Montevideo, and Universidade Federal do Rio Grande do Sul, Porto Alegre (UFRGS). Additional comparisons where done using published data from Reis \& Malabarba (1988) and Staeck (2006). Counts and measurements were taken according to Reis \& Malabarba (1988), with the addition of seven extra morphometric measures taken in straight line: snout to dorsal-fin origin length, snout to pelvic-fin origin length, snout to anal-fin origin length; and dorsal-, pelvic-, anal- and caudal-fin base lengths.

\section{Gymnogeophagus tiraparae, new species}

Figs. 1-2

Holotype. ZVC-P 7870, 99.7 mm SL, male, Uruguay, Tacuarembó, Pueblo Ansina, río Tacuarembó at Road 26, tributary of río Negro (lower río Uruguay drainage), 31 53'01'S, 55²8'38'W, Nov 2005 , M. Loureiro, F. Teixeira de Mello, S. Oviedo, A. D'Anatro \& I. González.

Paratypes. All from Uruguay. Lower río Uruguay drainage: ZVC-P 2690, 2, 45.2-52.2 mm SL, Durazno, Arroyo Cordobés, Estancia Las Pitangas, Cercanías de Paso del Gordo, 32³3'31', S, 55¹7'38"W, Jan 1963, Dolber; ZVC-P 3703, 2, 69.3-80.7 mm SL, Durazno, río Negro, Paraje 329, Road 6, 32²6’44"S, 55²6'03"W, Oct 1998, F. Achaval; ZVC-P 6684, 9, 42.9-60.3 mm SL, Durazno, río Yí, Paso San Borja, 3323'50"S, 56²4'10”W, Nov 2005, M.
Loureiro, F. Teixeira de Mello, S. Oviedo, A. D'Anatro \& I González:; ZVC-P 6687, 1, 57.2 mm SL, río Negro, Paraje 329, Road 6, Durazno, 32²6'44"'S, 55²6'03"W, Nov 2005, M. Loureiro, F. Teixeira de Mello, S. Oviedo, A. D’Anatro \& I. González; ZVCP 6688, 1, 72.9 mm SL, río Yí, Paso San Borja, Durazno, 33²3'50”S, $56^{\circ} 24^{\prime} 10^{\prime \prime} \mathrm{W}$, Nov 2005, M. Loureiro, F. Teixeira de Mello, S. Oviedo, A. D'Anatro \& I. González; ZVC-P 6689, 3, 47.1-65.9 mm SL, same data as holotype; ZVC-P 6692, 3, 58.9-79.5 mm SL, río Yí, Paso San Borja, Durazno, 3323'50”S, 56²4'10”W, 2005, Pablo Laurino; ZVC-P 6694, 1, 85.9 mm SL, río Yí, Paso San Borja, Durazno, 3323'50"S, 56 24'10"'W, 2005, Pablo Laurino; ZVC-P 6695, 1, 91.9 mm SL, río Negro, Paraje 329, Road 6, Durazno, 32²6'44' S, 55²6'03'W, Aug 2005, I. González; ZVC-P 7656, 2, 44.6-76.3 mm SL, río Yí, Polanco del Yí, Florida, 33¹8'45's, 56 09'08'"W, Mar 2008, M. Loureiro, F. Teixeira de Mello, M. Zarucki, L. Ziegler \& I. González; ZVC-P 7658, 1, 62.0 mm SL, río Tacuarembó Chico, Paso de los Novillos, Tacuarembó, 32¹1'09''S, 55'27'48', Mar 2008, F. Teixeira de Mello, M. Masdeu, G. Goyenola, M. Goyenola, J. Clemente \& I. González; ZVC-P 7938, 5, 62.3-97.1 mm SL, río Negro, embalse de represa de Baygorria, Durazno, 3252'21' S, 5648'13'W, Oct 2008, F. Teixeira de Mello \& Federico Viana; MNHN 3277, 6, 47.6-66.6 mm SL, same data as holotype. laguna Merin drainage: ZVC-P 7869, 1, $45.7 \mathrm{~mm}$ SL, río Tacuarí, Road 18, Cerro Largo, 3245'46”S, 5342'58'W, 2005, Pablo Laurino. UFRGS 10203, 3, 52.4-64.3mm SL, río Tacuarembó y ruta 26, Pueblo Ansina, Dpto Tacuarembó, 31 53 '01'”S, $55^{\circ} 28^{\prime} 38^{\prime}$ 'W, Nov 2005, M. Loureiro, A. D'anatro, F. Teixeira de Mello, S. Oviedo, I. González. UFRGS 10204, 2, 52.3-78.6 mm SL, río Yí, Paso San Borja, Durazno, 3323'50”S, 56²4'10”W, Nov 2005, I. González

Diagnosis. The new species can be distinguished from all others Gymnogeophagus species by the presence of the following unique characters: adipose hump on head deeper than the dorsal-fin upper border, adipose hump with anterior profile vertical, extending from the upper lip to the dorsal-fin origin, absence of transversal bands on body, two horizontal series of moderately elongated light blue dots between dorsal-fin spines, and a series of light blue stripes between soft rays, sometimes merged with the second series of elongated

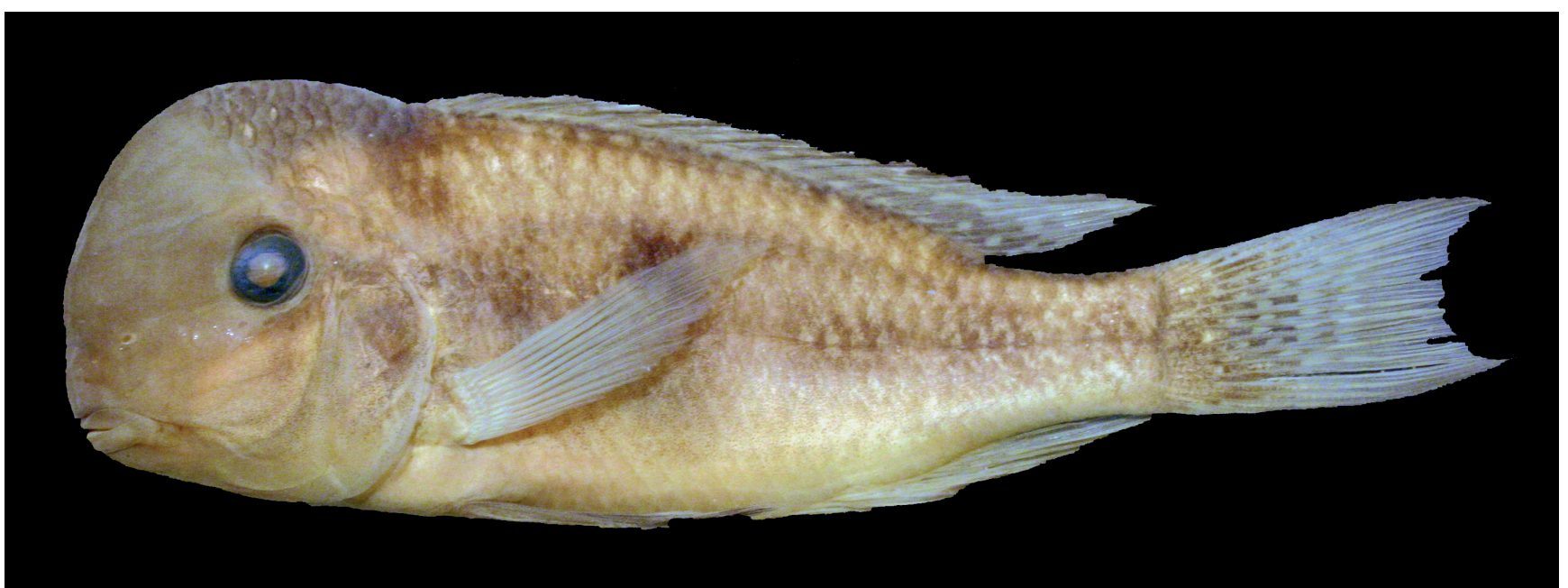

Fig. 1. Gymnogeophagus tiraparae, holotype, ZVC-P 7870, 99.7 mm SL, male, río Tacuarembó on Road 26, Pueblo Ansina, tributary to the río Negro (lower río Uruguay drainage). 
dots, and always with a red ground color between series of dots, and caudal fin with dots vertically aligned on its distal border. Gymnogeophagus tiraparae can be further distinguished from G. gymnogenys by the E1 scale count (27-30, 96\% with 28-30 vs. 26-29, 74\% with 26-27 in G. gymnogenys (Malabarba \& Reis, 1988)); from G. gymnogenys and $G$. caguazuensis by the absence of a black line anterior to eye (vs. present); from G. gymnogenys and G. australis by the body depth (33.6-41.4\% SL vs. 23-29\% SL and 41.2-43.3\% SL, respectively); from $G$. australis by the presence six to eight parallel light green bands on body ( $v S$. absence), by snout to dorsal-fin origin length (30.5-38.4\% SL vs. 23.6-30.7\% SL), and by the head depth (81-104\% HL vs. 109.7-116.2\% HL).

Description. Standard length of specimens examined 35.2 to $130.5 \mathrm{~mm}$; meristic and morphometric data in Table 1. Body elongated, laterally compressed. Predorsal contour convex. Reproductive males with adipose hump on top of head from dorsal-fin origin to upper lip, deeper than dorsal-fin upper border and with anterior profile vertical. Mouth terminal and jaws isognathus. Body contour at dorsal-fin base slightly arched, decreasing from anterior part to caudal peduncle. Caudal peduncle rectangular, longer than deeper, dorsal and ventral profiles slightly concave. Body contour slightly convex between lower lip and last anal-fin ray, with straight segment between pelvic and anal fins.

Body scales moderately large and ctenoid except for small cycloid and ctenoid scales in preventral area. Small ctenoid scales on opercle; scales on preopercle, when present, small and cycloid. Small ctenoid scales on base of hump (in adult reproductive males only) to approximately vertical line passing on center of eye.

Proximal third to half of caudal fin with small scales in single series between rays. Dorsal-fin without scales and its origin posterior to vertical line through posterior bony margin of opercle. Large males with sixth dorsal-fin soft ray longest, reaching proximal third of caudal fin. Pectoral fin reaching anal-fin origin. Anal fin reaching caudal-fin base. Caudal fin truncated or slightly concave; lyrate in large reproductive males; very deep distally, from distal edge of extended dorsal fin to distal edge of extended anal fin.

Color in life. Ground color of dorsal region of body in adults, brownish to light olivaceous, with one large dark spot on nape and two large dark spots on body flank, just below dorsal-fin base, first between eighth and twelfth dorsal-fin spine and second from first to sixth dorsal-fin soft ray. Well defined dark, circular, lateral spot just below upper portion of lateral line; often with three or four dark blotches on sides of body, anterior dark blotch larger and extending through lateral spot, other blotches smaller and aligned on sides, reaching caudal peduncle. Ventral portion of body yellowish in adult males and light olivaceus in adult females. Six or more lateral, parallel, bright green to pale blue bands from posterior part of pectoral-fin base to caudal-fin base.

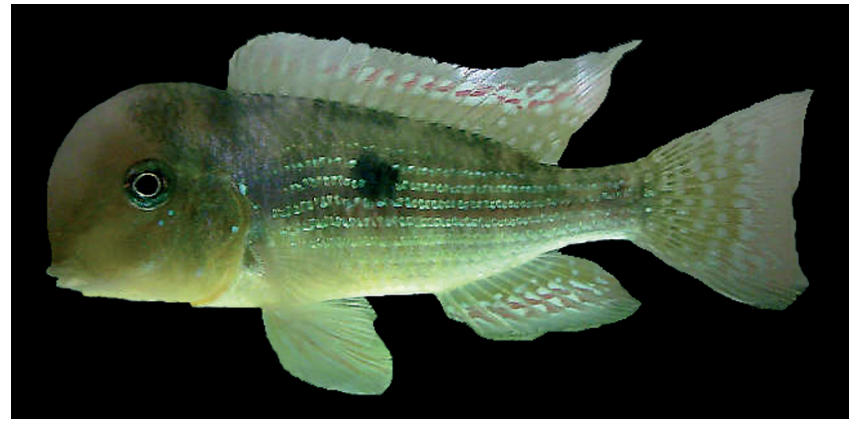

Fig. 2. Gymnogeophagus tiraparae, male not preserved from the río Yí, tributary to the río Negro (lower río Uruguay drainage).

Numerous small bright blue dots usually present on cheeks, bright green colored lips usually present in reproductive males. Adipose hump, when present, with brownish ground coloration without dark line anterior to eye, suborbital stripe usually absent or diffuse in reproductive males. Dorsal fin yellowish on base and reddish between two horizontal series of elongated, hyaline to light blue dots, and third distal series in posterior part of fin, often fused with proximal series; small proximal circular dots very close to dorsal-fin base often present, from the fifth or sixth dorsal-fin soft ray, to its distal end. Caudal fin with red ground color in adults and entirely covered with numerous circular hyaline dots, arranged into horizontal series between rays. Distal dots smaller, vertically aligned. Pectoral fin hyaline, pelvic fin with light blue stripes between fin rays; anal fin yellowish in proximal portion and reddish distally between many small light blue dots spread along fin.

Color in alcohol. Ground color turns paler. Reddish and yellowish pigmentations turn light brown or gray and light blue fin pigmentation turns hyaline. Dark spots turn darker and lateral parallel light green bands turn clearer, almost invisible.

Distribution. Gymnogeophagus tiraparae is distributed in the middle rio Negro basin, including main tributaries (lower río Uruguay basin) and in río Tacuarí (laguna Mirim basin) (Fig. 3).

Ecology. Localities where the new species was collected are large rivers, higher than stream order 6 , with clear water, sandy or rocky bottoms, and little vegetation. Specimens were collected using cast nets, seine and electro fishing device. Females holding juveniles in their mouths were collected at the end of spring and summer.

Etymology. Gymnogeophagus tiraparae takes its name from María Luisa Tirapare, a Guaraní woman who founded the now disappeared town of San Borja del Yí (close to the first locality where the new species was found), the last native town in Uruguayan land, where natives, fugitive African slaves, gauchos, and other outsiders lived together. 
Table 1. Frequency distribution of meristic characters of Gymnogeophagus tiraparae Paratypes and Holotype $(*) \mathrm{n}=38$.

\begin{tabular}{|c|c|c|c|c|c|c|c|c|c|c|c|c|c|c|c|c|c|c|c|}
\hline $\begin{array}{l}\text { Dorsal Fin } \\
\text { spines }\end{array}$ & XIII & XIII & XIII & XIV & XIV & XIV & $X V$ & XVI & & & & & & & & & & & \\
\hline soft rays & 7 & 11 & 12 & 7 & 10 & 11 & 8 & 9 & & & & & & & & & & & \\
\hline $\mathrm{n}$ & 1 & 5 & 1 & 1 & $24 *$ & 3 & 1 & 1 & & & & & & & & & & & \\
\hline $\begin{array}{l}\text { Anal Fin } \\
\text { spines }\end{array}$ & III & III & III & III & & & & & & & & & & & & & & & \\
\hline soft rays & 6 & 7 & 8 & 9 & & & & & & & & & & & & & & & \\
\hline $\mathrm{n}$ & 9 & $23^{*}$ & 3 & 1 & & & & & & & & & & & & & & & \\
\hline $\begin{array}{l}\text { Pectoral Fin rays } \\
\mathrm{n}\end{array}$ & & $\begin{array}{l}13 \\
38\end{array}$ & & & & & & & & & & & & & & & & & \\
\hline Lateral Line & 14 & 14 & 15 & 16 & 16 & 16 & 17 & 17 & 17 & 17 & 18 & 18 & 18 & 18 & 19 & 19 & 19 & 20 & 21 \\
\hline lower & 10 & 13 & 11 & 9 & 10 & 14 & 9 & 11 & 12 & 13 & 10 & 11 & $\begin{array}{l}10 \\
12\end{array}$ & $\begin{array}{l}10 \\
13\end{array}$ & 9 & 11 & & 14 & 12 \\
\hline $\mathrm{n}$ & 1 & 1 & 1 & 1 & 1 & 1 & 1 & 3 & 3 & 1 & 4 & 3 & $8^{*}$ & 1 & 1 & 4 & 1 & 1 & 1 \\
\hline E1 scale & 27 & 28 & 29 & 30 & & & & & & & & & & & & & & & \\
\hline $\mathrm{n}$ & 1 & 14 & $16^{*}$ & 7 & & & & & & & & & & & & & & & \\
\hline
\end{tabular}

\section{Discussion}

According to the molecular data presented by Pereyra \& García (2008), the new species described herein is assigned to the "gymnogenys-like" group of Gymnogeophagus. This is in agreement with the morphological analysis of the present description. Gymnogeophagus tiraparae shares with other members of the derived "gymnogenys-like" group the following characters: conspicuous secondary sexual dimorphism (including development of nuchal hump in reproductive males), mouth brooding reproductive system, high E1 scale count (27-30, 96\% with 28-30 scales), weak fin squamation, reduced sensory canal on caudal fin (Reis \& Malabarba, 1988; Winberger et al., 1998).

Pereyra and García (2008) found that G. tiraparae (clade 3 in fig. 3 of that article) is closely related to $G$. sp. 1 , with both

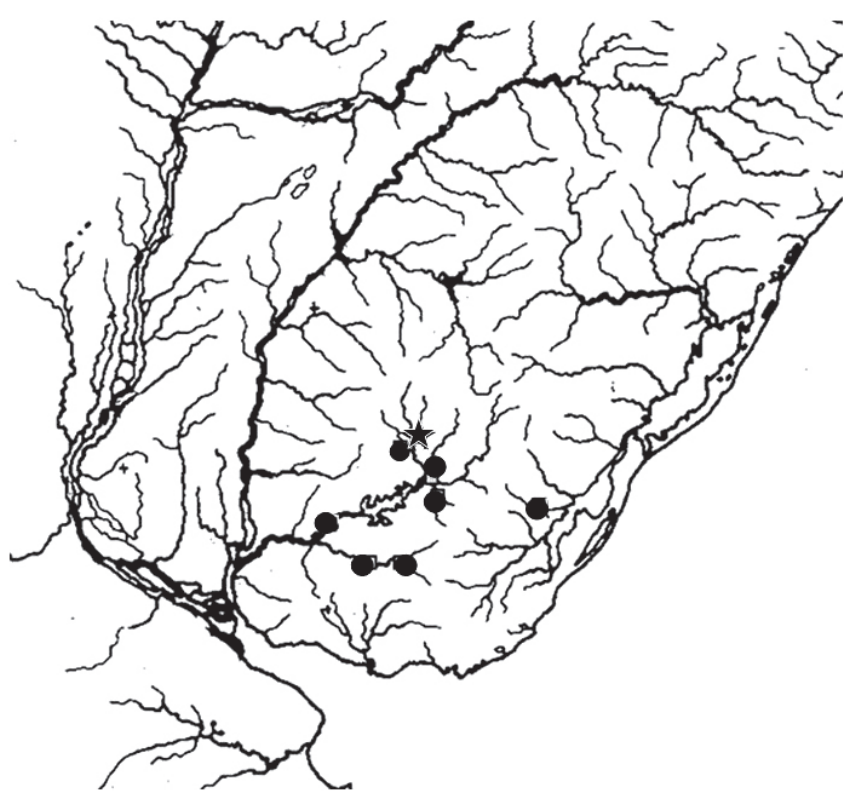

Fig. 3. Distribution of Gymnogeophagus tiraparae. Star $=$ type locality. species forming the sister group of $G$. sp. 3. The three species together represent the sister group of G. gymnogenys specimens from Rio Grande do Sul (Brazil). However, only the clades G. sp. 3, G. sp. 2 and G. tiraparae were supported by parsimony bootstrap values. It is interesting to note that $G$. sp. 3 presents all the diagnostic characteristics of G. gymnogenys from type locality (Reis \& Malabarba, 1988). For this reason further taxonomic work should include a revision of $G$. gymnogenys sensu stricto for a better understanding of the taxonomy and phylogeny of this group.

The new species is so far known from the río Negro and its tributaries (lower río Uruguay drainage), and río Tacuarí (laguna Merín drainage). This discontinuous distribution is shared, almost with the same pattern, with two species of the annual genus Austrolebias (Loureiro et al., 2004; Costa, 2006): A. arachan Loureiro, Azpelicueta \& García, A. vazferreirai Berkenkamp, Etzel, Reichert \& Salvia. Most populations of these species are present along río Negro basin, while their distribution in the laguna Merin drainage is restricted to a small area of highland wetlands ( $100 \mathrm{~m}$ above sea level) in the upper rio Tacuarí, that is geographically close to río Negro tributaries (as close as $10 \mathrm{~km}$ ) (Loureiro et al. 2004). In a broader geographical scale the biogeographic relationship of these two areas has been proposed as a result of basin capture (Ribeiro, 2006) and marine transgressions and regressions (Loureiro, 2004; Loureiro \& Garcia, 2006). Ribeiro (2006), reviewed the geological and geomorphological relationship between Atlantic coastal basins and their adjacent upland cristalline shield, and the concomitant fish distributions patterns that arose from this relationship, where headwaters of the cristalline shield rivers are constantly being captured by the Atlantic rivers. This author identified three different distribution patterns according to their time of occurrence. An ancient pattern exemplified by the presence of basal clades of Trichomicteridae and Doradidae in Atlantic rivers; an intermediate pattern exemplified by sister group relationships at the generic level as in the Aspidoradini (Callichthyidae), the sister group relationship of Lignobrycon and Triportheus (Characidae), and others (see Ribeiro, 2006); and a recent 
pattern exemplified by the shared presence of the same species in both regions. In the case of the Patos-Merin system and the Uruguay river basin, the examples cited by Ribeiro are two species of Cnesterodon, two species of Hypostomus, and one species of Bryconamericus; with the recently described Brachyhypopomus bombilla Loureiro \& Silva and Brachyhypopomus draco Giora, Malabarba \& Crampton as additional examples (Loureiro \& Silva, 2006; Giora et al., 2008). The distribution of G. tiraparae and the Austrolebias species mentioned before correspond to that recent pattern and, based on the highly restricted distribution of these taxa in laguna Merín drainage (so far, only known from the Tacuarí River basin), it is likely to represent one the most recent events.

Comparative material. All from Uruguay. Gymnogeophagus australis. Lower río Uruguay drainage: ZVC-P 7414, 4, 70.3-94.6 mm SL, río Uruguay, Villa Constitución, Salto; ZVC-P 7464, 1, 93.0 mm SL, río Uruguay, $\mathrm{A}^{\circ}$ Yaguareté, río Negro: MNHN 378, 1, 98 $\mathrm{mm}$ SL, río Uruguay, Paysandú city, Paysandú. río de la Plata drainage: MNHN 1491, 1,>100 mm (broken caudal peduncle) SL, A Limetas, Colonia. Gymnogeophagus labiatus. laguna Merín drainage: ZVC-P 6080, 2, 35.2-40.4 mm SL, río Cebollatí, Paso del Rey, Lavalleja; ZVC-P 6085, 1, 64.3 mm SL; ZVC-P 6168 1, 67.9 mm SL, río Yaguarón, Paso Centurión, Cerro Largo; ZVC-P 6093, 4, 48.4-57.1 mm SL, A ${ }^{\circ}$ de las Averías, Paso del Aguila, Rocha; ZVCP 6286, 1, $55.5 \mathrm{~mm}$ SL, río Olimar Chico, Paso de Palo a Pique, Treinta y Tres. Gymnogeophagus sp. 1. Lower río Uruguay draingae: ZVC-P 166, 6, 44.9-87.2 mm SL, A Isleta, Salto; ZVC-P 2739, 2, 53.1-77.1 mm SL, río Arapey, Salto; ZVC-P 4124, 6, 50.877.3 mm SL, ZVC-P 4124, 6, 50.8-77.3 mm SLA A Catalán Grande, Paso Urumbeba, Artigas; ZVC-P 6693, 3, 63.6-92.2 mm SL; MNHN 1616, 13, 32-71 mm SL A $^{\circ}$ Pintado, Artigas; MNHN 2594, 5, 50-76 mm SL, $\mathrm{A}^{\circ}$ Catalán Grande, Artigas. Gymnogeophagus sp. 2: ZVCP 3450, 5, 64.3-78.8 mm SL, A ${ }^{\circ}$ Milano, Florida (río de la Plata drainage). Gymnogeophagus sp. 3. Lower río Uruguay drainage: ZVC-P 2472, 1, 66.2,mm SL, A ${ }^{\circ}$ Cuñapirú, tributary to río Tacuarembó, Tacuarembó; ZVC-P 2659, 3, 49.2-86.3 mm SL, A ${ }^{\circ}$ Cordobés, Durazno; ZVC-P 2806, 1, 71.3 mm SL, A Cordobés, 28 km NW From Cerro Chato, Treinta y Tres; ZVC-P 2809, 2, 55.7$57.6 \mathrm{~mm}$ SL, $\mathrm{A}^{\circ}$ Cuñapirú, tributary to río Tacuarembó, Tacuarembó; ZVC-P 3699, 2, 47.9-82.9 mm SL, A ${ }^{\circ}$ Laureles, tributary to río Tacuarembó, Tacuarembó; ZVC-P 3703, 1, 60.4 mm SL, río Negro, Road 6, Paraje 329, Durazno; ZVC-P 3713, 2, 53.6-86.4, A ${ }^{\circ}$ Laureles, tributary to río Tacuarembó, Tacuarembó; ZVC-P 3907, 1, 73 mm $\mathrm{SL}, \mathrm{A}^{\mathrm{o}}$ Jabonería, tributary of $\mathrm{A}^{\mathrm{o}}$ Tacuarembó chico, Tacuarembó; ZVC-P 4058, 1, $92.8 \mathrm{~mm} \mathrm{SL}, \mathrm{A}^{\circ}$ Las Higueras, tributary of $\mathrm{A}^{\mathrm{o}}$ Carpintería, Durazno; ZVC-P 4122, 2, 43.9-50.4 mm SL, río Uruguay, Nuevo Berlín, río Negro; ZVC-P 4411, 2, 50-53.4 mm SL, A ${ }^{\circ}$ Tacuarembó chico, Ciudad de Tacuarembó, Playa del Tati, Tacuarembó; ZVC-P 6696, 1, 78.4 mm SL, río Yí, Paso San Borja, Durazno. río de la Plata drainage: ZVC-P 1259, 3 specimens, 88102.4 mm SL, río Santa Lucía, Arequita, Lavalleja; ZVC-P 3706, 1, $61.9 \mathrm{~mm} \mathrm{SL}, \mathrm{A}^{\circ}$ Mataojo, Aguas Blancas, Lavalleja; ZVC-P 4123, 1, $62.4 \mathrm{~mm} \mathrm{SL}, \mathrm{A}^{\circ}$ Sauce, Solís de Mataojo City, Lavalleja; ZVC-P 4386, 1, 92.8 mm SL, río Santa Lucía, Santa Lucía city, Canelones; ZVC-P 5772, 1, 72.7 mm SL, río Santa Lucía, Arequita; ZVC-P 5814, 1, 51.9 mm SL, A ${ }^{\circ}$ Mataojo, Aguas Blancas; ZVC-P 7762, 5, 40.4-64.8 mm SL, río Santa Lucía, Florida; ZVC-P 7767, 3, 73.5110.4 mm SL, A Colla, Colonia; MNHN 1382, 1, 105 mm SL, río
Santa Lucía, 25 de Agosto town, Florida; MNHN 1791, 5, 52-69 $\mathrm{mm} \mathrm{SL}, \mathrm{A}^{\circ}$ Chamizo, tributuary to río Santa Lucía, Florida. Atlantic Ocean drainage: ZVC-P 3783, 1, 58.8 mm SL, A Martín Soroba, near Rocha City, Rocha. laguna Merín drainage: ZVC-P 483, 1, 55.8 mm SL, río Cebollatí, Picada de Techera, Lavalleja; ZVC-P 4490, 1, 79.6 mm SL, río Yaguarón, Cerro Largo; ZVC-P 6078, 1, 55.6 mm SL, río Cebollatí, Paso de las Averías, Road 14, Rocha; ZVC-P 6277, 2, 40.8-66.8 mm SL, río Tacuarí, Paso de los Carros, Cerro Largo; ZVC-P 7764, 7, 42.1-67.7 mm SL, río Tacuarí, Road 18, Cerro Largo; ZVC-P 7765, 5, 51.7-99.2 mm SL, río Yaguarón, Cerro Largo; MNHN 486 , 4, 71.0-12.3 mm SL, A Conventos, tributary to río Tacuarí, Cerro Largo.

\section{Aknowledgements}

We thank Tito Olivera, F. Teixeira de Mello, and A. D'Anatro for field trip assistance, A. Duarte for providing live specimen picture, G. García and S. Pereyra for specimens donated, Luciana Melo for the Portuguese translation, and the two reviewers that greatly improved the manuscript. This study was partially funded by a PDT grant to Marcelo Loureiro and CSIC (Universidad de la República, Uruguay).

\section{Literature Cited}

Costa, W. E. J. M. 2006. The South American annual killifish genus Austrolebias (Teleostei: Cyprinodontiformes: Rivulidae): phylogenetic relationships, descriptive morphology and taxonomic revision. Zootaxa, 1213: 1-162.

Giora, J., L. R. Malabarba \& W. Crampton. 2008. Brachyhypopomus draco, a new sexually dimorphic species of Neotropical electric fish from southern South America (Gymnotiformes: Hypopomidae). Neotropical Ichthyology, 6(2):159-168.

Kullander, S. O. 2003. Family Cichlidae. Pp. 605-654. In Reis, R. E., S. O. Kullander \& C. J. Ferraris (eds.), Check List of the Freshwater Fishes of South and Central America. Porto Alegre, Edipucrs, 709 p.

López-Fernández, H., R. L. Honeycutt \& K. O. Winemiller. 2005a. Molecular phylogeny and evidence for an adaptive radiation of geophagine cichlids from South America (Perciformes: Labroidei). Molecular Phylogenetics and Evolution, 34: 227-244.

López-Fernández, H., R. L. Honeycutt, M. L. J. Stiassny \& K. O. Winemiller. 2005b. Morphology, molecules, and character congruence in the phylogeny of South American geophagine cichlids (Perciformes, Labroidei). Zoologica Scripta, 34: 627-651.

Loureiro, M. 2004. Sistemática y biogeografía de los peces anuales de la subtribu Cynolebiatina (Cyprinodontiformes: Rivulidae: Cynolebiatinae). Unpublished Ph.D. dissertation, Universidad de la República PEDECIBA, Montevideo. 119 p.

Loureiro, M., M. Azpelicueta \& G. García. 2004. Austrolebias arachan (Cyprinodontiformes, Rivulidae), a new species of annual fish from northeastern Uruguay. Revüe Suisse de Zoologie, 111(1): 21-30.

Loureiro, M. \& G. García. 2006. Transgresiones y regresiones marinas en la costa Atlántica y lagunas costeras de Uruguay: efectos sobre los peces continentales. In: Vida Silvestre Uruguay. Pp: 545-555. In Menafra, R., L. Rodríguez-Gallego, F. Scarabino, \& D. Conde (eds.), Bases para la conservación y el manejo de la costa uruguaya. Vida Silvestre Uruguay, Montevideo, 668 p.

Loureiro, M. \& A. Silva. 2006. A new species of Brachyhypopomus (Gymnotiformes, Hypopomidae) from northeast Uruguay. 
Copeia, 2006 (4): 667-673.

Pereyra, S. \& G. García. 2008. Patterns of genetic differentiation in the Gymnogeophagus gymnogenys species complex, a neotropical cichlid from South American basins. Environmental Biology of Fishes 83(3): 245-257.

Reis, R. E. \& L. R. Malabarba. 1988. Revision of the Neotropical genus Gymnogeophagus Ribeiro, 1918 with descriptions of two new species (Pisces, Perciformes). Revista Brasileira de Zoología, 4: 259-305.

Ribeiro, A. C. 2006. Tectonic history and the biogeography of the freshwater fishes from the coastal drainages of eastern Brazil: an example of faunal evolution associated with a divergent continental margin. Neotropical Ichthyology, 4(2): 225-246.

Staeck, W. 2006. Gymnogeophagus caaguazuensis sp. n. - a new species of cichlid fish (Teleostei, Perciformes, Labroidei) from the drainage of the lower rio Paraguay in Paraguay. Zoologische Abhandlungen, 56: 99-105.

Wimberger, P. H., R. E. Reis, K. R. Thornton. 1998. Mitochondrial Phylogenetics, Biogeography, and evolution of parental care and mating system in Gymnogeophagus (Perciformes: Cichlidae). Pp: 509-518. In Malabarba, L. R., R. E. Reis., R. P. Vari., Z. M. S. Lucena \& C. A. S. Lucena (eds.), Phylogeny and classification of Neotropical fishes. Porto Alegre, Edipucrs, 603 p.

Accepted February, 2009

Published March 31, 2009 